\title{
The Role of E-Learning in Learning
}

\author{
Siti Nurmiati ${ }^{1}$, Abdul Karim bin Mohamad ${ }^{2}$, Sazalinsyah bin Razali ${ }^{3}$ \\ \{snurmiati@gmail.com¹,karim@utem.edu.my ${ }^{2}$, sazalinsyah@utem.edu.my ${ }^{3}$ \} \\ Institut Sains dan Teknologi Nasional ${ }^{1}$, University of Technical Malaysia Malaca ${ }^{2,3}$
}

\begin{abstract}
This study aims to examine research instruments regarding the role of eLearing in Universities located in Indonesia. Data obtained from the questionnaire field are distributed online and have been filled by as many as 100 respondents with a population of e-learning users from various professional backgrounds. The questionnaire was filled by 100 respondents with different professional backgrounds, namely students, lecturers, teachers, employees, entrepreneurs, civil servants, and then collected and processed data by testing using inductive or inferential statistics. The method used is a qualitative method, while testing includes validity and reliability, chi square test, $t$ test, $f$ test and classic assumption test in multiple linear regression by processing data using SPSS version 24 , by testing the validity and reliability based on data that has been tested from Y to X8 the value of Cronbach's Alphanya 0.984>0.1654 means that the data is tested for reliability.
\end{abstract}

Keywords: e-Learning, Effective, Efficient, Validity, Reliability

\section{Introduction}

Presenting and creating a high quality education and making fundamental changes to make the Unitary State of the Republic of Indonesia from a developing country as a developed, prosperous, just and prosperous country as aspired to the nation's founders and all the people of Indonesia also set out in the Opening of the Constitution of the Republic of Indonesia In 1945 that to form an Indonesian Government that protects all Indonesian people and all Indonesian blood and to promote public welfare, educate the nation's life, and participate in carrying out world order based on independence, lasting peace and social justice[1].

To produce superior and high quality education it has been realized by the leaders of the Indonesian movement and is the ideals of all the people of Indonesia, starting in 1908 the National awakening, set out in Article 31 of the 1945 Constitution of the Republic of Indonesia that every citizen has the right to education[1].

As part of the national education system, higher education has a strategic role in educating the nation's life and advancing science and technology as well as to enhance the nation's competitiveness in the face of globalization in all fields, so the government is required to produce educational policies.

The Government has established policies in the administration of national education, contained in Law of the Republic of Indonesia Number 12 of 2012 concerning Higher Education, Law of the Republic of Indonesia Number 20 of 2003 concerning the National 
Education System replaces Law of the Republic of Indonesia Number 2 of 1989 Concerning National Education System. Besides stipulated in the law, there are also other policies contained in Government Regulation of the Republic of Indonesia Number 4 of 2014 concerning the Implementation of Higher Education and Management of Higher Education, Government Regulation of the Republic of Indonesia Number 13 of 2015 concerning Second Amendment to Government Regulation Number 19 of 2005 concerning National Education Standards, Government Regulation of the Republic of Indonesia Number 19 of 2005 concerning National Education Standards, Government Regulation of the Republic of Indonesia Number 32 of 2013 concerning Amendment to Government Regulation Number 19 of 2005 concerning National Education Standards, Government Regulation of the Republic of Indonesia Number 66 Year 2010 concerning Amendments to Government Regulation Number 17 of 2010 concerning Management and Implementation of Education, Regulation of the Minister of Education and Culture of the Republic of Indonesia Number 49 of 2014 concerning National Standards of Higher Education.

The rapid development of technology makes the education system in Indonesia continue to experience better development and more advanced to follow other countries. The education system in Indonesia, which is still using conventional systems, is now beginning to switch to digital systems, the learning process that only occurs in classrooms and learning schedules, now the learning process is not bound by space and time, it can be done anytime and anywhere using the internet.

With the introduction of the internet world, especially e-learning learning, that is by using Internet technology that can improve learning knowledge and performance and have advantages that students can choose (place and time of learning), compared to conventional learning conducted in the classroom.

E-learning is a learning system based on formal teaching but with the help of electronic resources[2]. e-Learning is learning to use electronic technology to access educational curricula outside traditional classrooms. In most cases, this refers to the program, program or degree that is delivered online. The learning process can be done inside or outside the classroom, computers and the internet is a form of major components of the application of elearning[3]. Learning E-learning uses electronic technology to access educational curricula outside traditional classrooms[4].

With the application of e-learning, of course Universities that have carried out the process of higher education learning want to know the extent of the results rather than the application of e-learning that has been implemented in tertiary institutions.

Reading is one of the important phases in the learning process, Learning efficiently depends on the presentation of information that can be requested and accessed through the internet in the e-learning system. whereas effective learning is related to influence by recognizing and understanding human emotions.

From this background, this study discusses the effectiveness and efficiency of the role of e-learning within the university. Some research related to the e-Learning in learning environment is available and can be found in world databases such as Scopus, Springer or ScienceDirect. The research includes : which shows the creation of expert e-learning system content based on tree data structures using artificial intelligence[5], to explore the concepts of cloud computing and e-learning and their benefits if these two technologies are combined with the intended use by higher education institutions[6], to clarify the basic concepts and advantages of E-Learning and find a vision of using information and communication technology for the electronic learning process in facing the challenges of this century and future problems[7], a new technique for face recognition, this technique has a large 
application level including identification, authentication, psychology, e-learning, security, marketing and human interaction and computer[8], the main role of the Web Socket protocol in an E-learning system can transfer a number of data without the overhead associated with traditional HTTP[9], e-Learning Model for Equivalency Education Program in Indonesia, proposes an E-Learning model to support non-formal education in Indonesia. This model is referred to as E-learning for the Equality Education Program Model (E-LEEP) consisting of three components: Users, Education Programs, and Monitoring[10], the influence of motivation in the context of the use of e-learning to facilitate the learning process, improve student performance, and to observe the literature in the use of e-learning. to ensure that elearning is part of a blended learning system that can optimize student learning experiences[11], involving students in e-learning learning for a longer duration of time, in a learning atmosphere and adaptive learning content to express students' emotional behavior[12], the involvement of the use of ICT to teach and deliver learning material, the readiness of students to use the University e-Learning system to improve learning efficiency and opportunities and the results show, the most important factors are confident e-learning and e-learning training not e-learning readiness[13]. Factors influencing learning outcomes related to e-learning and blended learning include the presence of educators in online settings, interactions between students, teachers and the contents of the material / content, connections designed between online and offline activities related to related practices[14].

The world of education is growing very rapidly followed by the trend of teaching that uses e-learning as a teaching and learning activity by utilizing ICTs as one of the roles of mobile phones to implement teaching and learning activities. Mobile phones are not only used for communication, texting and other activities, the latest mobile phones provide a simple and easy way to develop teaching and learning activities, therefore, on this occasion we will examine the effective and efficient e-Learning learning media at universities located in Indonesia. Building user attitudes towards computers and Internet technology can be divided into three main measures : measurement of affective, cognitive, and behavioral. Affective measurement such as pleasure perception, cognitive measurement such as perceptions of selfefficacy and perceived usefulness have a positive effect on behavioral measurement such as behavioral intention to use e-learning as a teaching or learning tool[15].

In addition to growing with the internet, computers, instant messaging, video games and cell phones, the "millennial" generation as it is known, has very different views on access to information than their parents and grandparents (Prensky, 2001). To design an effective elearning environment, Liaw (2004) suggests three considerations : student characteristics, teaching structure, and interaction. In developing e-learning, it is necessary to understand the targeted population. First, learner characteristics, such as attitudes, motivations, beliefs, and beliefs need to be identified (Passerini \& Granger, 2000). Basically, e-learning signifies an independent learning environment. In other words, users have more opportunities to learn independently in an e-learning environment. As for the structure of teaching, multimedia instruction allows students to develop complex cognitive skills, such as understanding important elements of conceptual complexity, the ability to use concepts obtained for reasoning and inference, and the competence to apply conceptual knowledge to new situations with flexibility (Spiro, Feltovich, Jacobson, \& Coulson, 1995). Finally, the e-learning environment offers group interaction, such as students to students, or students to instructors. 
Group interaction is a type of cooperative learning that helps students make progress through their zones of proximal development with the activities in which they are involved (Vygotsky, 1978). When students increase their interaction with instructors and students, they in turn increase their opportunities to build their own knowledge because a lot of unavoidable learning occurs in social contexts, and the process involves constructing mutual understanding (Bruner, 1971). So, based on fundamental e-learning criteria, these are three considerations in designing an e-learning environment: independent learning, a multimedia environment, and teacher-assisted learning. Previous research (Triandis, 1971) suggested that attitudes consist of components of affective, cognitive, and behavioral. Affective components are emotions or feelings that include statements of likes or dislikes for certain objects. The cognitive component refers to a statement of belief. And the component of behavior is what individuals actually do or want to do[16].

This study investigates the effectiveness of using e-learning in teaching in tertiary institutions. In institutions of higher education, the issue of utilizing modern information and communication technologies for teaching and learning is very important. This study reviews literature and gives a scholarly background to the study by reviewing some contributions made by various researchers and institutions on the concept of e-learning, particularly its usage in teaching and learning in higher educational institutions. It unveils some views that people and institutions have shared globally on the adoption and integration of e-learning technologies in education through surveys and other observations. It looks at the meaning or definitions of e-learning as given by different researchers and the role that e-learning plays in higher educational institutions in relation to teaching and learning processes, and the advantages and disadvantages of its adoption and implemention. E-learning involves the use of digital tools for teaching and learning. It makes use of technological tools to enable learners study anytime and anywhere. It involves the training, delivery of knowledge and motivates students to interact with each other, as well as exchange and respect different point of views. It eases communication and improves the relationships that sustain learning. Despite some challenges discussed, the literature has sought to explain the role of elearning in particular and how eLearning has made a strong impact in teaching and learning. Its adoption in some institutions has increased faculty and learner's access to information and has provided a rich environment for collaboration among students which have improved academic standards. The overall literature which explains the advantages and disadvantages of elearning suggests the need for its implementation in higher education for faculty, administrators and students to enjoy the full benefits that come with its adoption and implementation[3]. In the formulation of this problem, how to measure the effective and efficient e-Learning in one of the universities located in Indonesia. In the research objectives: first, examine the level of the relationship between the independent variable and the dependent variable. Second, examine the relationship between variables, so that the results can be known effective and efficient learning by e-Learning. 


\section{Research Methodology}

Data for this study were collected using a questionnaire distributed via online. The questionnaire includes : (1) The role of e-Learning (2) Demographics of questionnaire fillers. The details of each questionnaire, First : Fields related to the role of e-Learning in learning, respondents answered statements from 81 items that included discussion of e-Learning, System Performance, System Security, E-Readiness, Behavior, Management, Effectiveness, Efficiency, Organizing Institution.

The statements use a scale of measurement using a Likert scale starting with a value or number that is 4 value "Strongly Agree", 3 value "Agree", 2 value "Disagree" and 1 value "Disagree". After processing the data it results that there is an effective and efficient connection between users and e-Learning learning (results show on tables 1). Second : Fields relating to the respondent's demographics include name, institution, address, application used, gender, age, education, occupation. Research of methodology by using qualitative approach.

\section{Results and Discussion}

\subsection{The results}

The result obtained based on the questionnaire that has been processed using SPSS version 24, regarding the relationship between independent and dependent variables concerning e-learning variables with variables (System Performance, System Security, eReadiness, Behavior, Management, effective, efficient and Organizing Institution) the results of this test indicate a relationship.

Table 1. Univariat Demographics

\begin{tabular}{|c|c|c|c|c|c|c|}
\hline \multirow{2}{*}{ No } & \multirow{2}{*}{\multicolumn{2}{|c|}{ Variable }} & \multicolumn{3}{|c|}{ e-Learning } & \multirow{2}{*}{ Result } \\
\hline & & & Active & Unactive & Total & \\
\hline \multirow[t]{3}{*}{1} & Gender & 1. Male & 75 & 4 & 79 & \multirow{3}{*}{$\begin{array}{l}\text { There is not } \\
\text { relationship }\end{array}$} \\
\hline & & 2. Female & 19 & 2 & 21 & \\
\hline & & Total & 94 & 6 & 100 & \\
\hline \multirow[t]{6}{*}{2} & Age & 1. $18-25$ & 74 & 4 & 78 & \multirow{6}{*}{$\begin{array}{l}\text { There is } \\
\text { relationship }\end{array}$} \\
\hline & & 2. $26-35$ & 8 & 1 & 9 & \\
\hline & & 3. $36-45$ & 2 & 2 & 4 & \\
\hline & & 4. $46-55$ & 3 & 1 & 4 & \\
\hline & & 5. $>55$ & 4 & 1 & 5 & \\
\hline & & Total & 91 & 9 & 100 & \\
\hline \multirow[t]{3}{*}{3} & Address & 1. Outside Institution & 24 & 2 & 26 & \multirow{3}{*}{$\begin{array}{l}\text { There is not } \\
\text { relationship }\end{array}$} \\
\hline & & 2. Inside Institution & 71 & 3 & 74 & \\
\hline & & Total & 95 & 5 & 100 & \\
\hline \multirow[t]{4}{*}{4} & Education & 1. Student \& College Students & 35 & 1 & 36 & \multirow{4}{*}{$\begin{array}{l}\text { There is not } \\
\text { relationship }\end{array}$} \\
\hline & & 2. Diploma & 2 & 1 & 3 & \\
\hline & & 3. $\mathrm{S} 1$ & 43 & 2 & 45 & \\
\hline & & 4. $>\mathrm{S} 2$ & 15 & 1 & 16 & \\
\hline
\end{tabular}




\begin{tabular}{|c|c|c|c|c|c|c|c|}
\hline \multirow{2}{*}{$\mathrm{Nc}$} & & \multirow{2}{*}{ Variable } & & \multicolumn{3}{|c|}{ e-Learning } & \multirow{2}{*}{ Result } \\
\hline & & & & Active & Unactive & Total & \\
\hline & & & Total & 95 & 5 & 100 & \\
\hline \multirow[t]{6}{*}{5} & Job & 1. College Student & & 70 & 5 & 75 & \\
\hline & & 2. Employee & & 5 & 3 & 5 & \\
\hline & & 3. Civil servants & & 2 & 0 & 2 & There is \\
\hline & & 4. Lectures/Teachers & & 12 & 2 & 14 & relationship \\
\hline & & 5. Other & & 1 & 0 & 2 & \\
\hline & & & Total & 90 & 10 & 100 & \\
\hline
\end{tabular}

In table 1 shown the relationship of variables to demographics with e-learning that have a relationship or there is a relationship that occurs at age and occupation while those with no relationship occur in gender, address and education. e-Learning is active on demographics has an overall impact (93\%), includes gender (94\%), age (91\%), address $(95 \%)$, education $(95 \%)$ and job (90\%). e-Learning is active based on gender $(47 \%)$, includes male $(75 \%)$, and female (19\%). e-Learning that is active based on the overall age (20\%), 18-25 years (81\%), 26-35 years $(9 \%), 36-45$ years $(2 \%), 46-55$ years $(3 \%)$ and $>55$ years $(4 \%)$. e-Learning is active based on overall address (48\%), includes inside institution (24\%), and outside institution (71\%). e-Learning that is active based on education $(24 \%)$, includes Students \& Collage Students (37\%), Diploma (1\%), S1 (45\%), and S2 (26\%). e-Learning is active based on the overall jobs (18\%), includes Students (78\%), Employees (6\%), civil servants $(2 \%)$, lecturers / teachers $(13 \%)$ and others $(1 \%)$. e-Learning is active on Demographics based on gender is male, age is $18-25$ years, address is outside institution, education is $\mathrm{S} 1$ and job is student.

Table 2. Relations between Variables

\begin{tabular}{|c|c|c|c|c|c|c|c|}
\hline No & & Variable & & Active & $\begin{array}{c}\text { e-Learning } \\
\text { Unactive }\end{array}$ & Total & Result \\
\hline \multirow[t]{3}{*}{1} & System & 1. Performance & & 96 & 1 & 97 & \multirow{3}{*}{$\begin{array}{l}\text { There is } \\
\text { relationship }\end{array}$} \\
\hline & Performance & 2. Unperformance & & 2 & 1 & 3 & \\
\hline & & & Total & 98 & 2 & 100 & \\
\hline \multirow[t]{3}{*}{2} & System Security & 1. Secure & & 96 & 0 & 96 & \multirow{3}{*}{$\begin{array}{l}\text { There is } \\
\text { relationship }\end{array}$} \\
\hline & & 2. Unsecure & & 3 & 1 & 4 & \\
\hline & & & Total & 99 & 1 & 100 & \\
\hline \multirow[t]{3}{*}{3} & e-Readiness & 1. e-Readiness & & 94 & 0 & 94 & \multirow{3}{*}{$\begin{array}{l}\text { There is } \\
\text { relationship }\end{array}$} \\
\hline & & 2. Un e-Readiness & & 5 & 1 & 6 & \\
\hline & & & Total & 99 & 1 & 100 & \\
\hline \multirow[t]{9}{*}{4} & Behavior & 1. Honest & & 15 & 2 & 17 & \multirow{9}{*}{$\begin{array}{l}\text { There is } \\
\text { relationship }\end{array}$} \\
\hline & & 2. Not Honest & & 0 & 1 & 1 & \\
\hline & & 1. Trust & & 21 & 2 & 23 & \\
\hline & & 2. Not Trust & & 0 & 1 & 1 & \\
\hline & & 1. Messanger & & 21 & 4 & 25 & \\
\hline & & 2. Unmessanger & & 0 & 2 & 2 & \\
\hline & & 1. Intelligent & & 22 & 7 & 29 & \\
\hline & & 2. Not Intelligent & & 0 & 2 & 2 & \\
\hline & & & Total & 79 & 21 & 100 & \\
\hline \multirow[t]{3}{*}{5} & Management & 1. Management & & 95 & 1 & 96 & \multirow{3}{*}{$\begin{array}{l}\text { There is } \\
\text { relationship }\end{array}$} \\
\hline & & 2. Not Management & & 3 & 1 & 4 & \\
\hline & & & Total & 98 & 2 & 100 & \\
\hline 6 & Efective & 1. Efective & & 80 & 2 & 82 & There is \\
\hline
\end{tabular}




\begin{tabular}{|c|c|c|c|c|c|c|}
\hline \multirow{2}{*}{$\mathrm{N}$} & & \multirow{2}{*}{ Variable } & \multicolumn{3}{|c|}{ e-Learning } & \multirow{3}{*}{$\begin{array}{l}\text { Result } \\
\text { relationship }\end{array}$} \\
\hline & & & Active & Unactive & Total & \\
\hline & & \multirow[t]{2}{*}{ 2. Not Efective } & 3 & 15 & 18 & \\
\hline & & & 83 & 17 & 100 & \\
\hline \multirow[t]{3}{*}{7} & Eficiency & 1. Eficiency & 97 & 1 & 98 & \multirow{3}{*}{$\begin{array}{l}\text { There is } \\
\text { relationship }\end{array}$} \\
\hline & & 2. Not Eficiency & 1 & 1 & 2 & \\
\hline & & Total & 98 & 2 & 100 & \\
\hline \multirow[t]{3}{*}{8} & Organizing & 1. Organizing Institution & 96 & 1 & 97 & \multirow{3}{*}{$\begin{array}{l}\text { There is } \\
\text { relationship }\end{array}$} \\
\hline & Institution & $\begin{array}{l}\text { 2. Not Organizing } \\
\text { Institution }\end{array}$ & 1 & 2 & 3 & \\
\hline & & Total & 97 & 3 & 100 & \\
\hline
\end{tabular}

In table 2 shown the relationship between variables with e-learning all shows a relationship with these variables including system performance, system security, e-readiness, behavior, management, effective, efficient and organizing institutional.

Active e-Learning has an overall impact $(92 \%)$, detail on system performance $(96 \%)$, system security (96\%), e-Readiness (94\%), behavior (79\%), management $(95 \%)$, effective $(80 \%)$, efficient (97\%) and institutions (96\%). e-Learning is active on system performance $(50 \%)$, includes performance $(98 \%)$ and unperformance $(2 \%)$.

E-Learning is active based on overall system security (50\%), includes (96\%), unsecure (3\%). E-Learning is active based on overall e-readiness (50\%), includes e-readiness $(94 \%)$ and not e-readiness $(6 \%)$. E-Learning is active based on behavior $(79 \%)$, includes honesty (60\%), trust $(84 \%)$, messanger $(84 \%)$ and intelligence $(84 \%)$. e-Learning is active based on overall management $(50 \%)$, include management $(97 \%)$, unmanagement $(3 \%)$. e-Learning is active based on overall effective $(50 \%)$, include effective $(94 \%)$ and in-effective $(6 \%)$. e-Learning is active based on overall Efficiency (50\%), includes efficiency (94\%), in-efficient (6\%). eLearning is active based on the Institution (50\%), include institutions (94\%) and not institutions $(6 \%)$. The relationship between variables with e-learning all shows a relationship with these variables including system performance, system security, readiness, behavior, management, effective, efficient and institution. e-Learning is the relationship between variables with e-learning has a dominant impact based on : system performance that is performing (existing), System security which is safe, e-Readiness namely e-readiness, Behavior that is smart, Management namely management, Effective, namely effective, efficient, that is efficient, Institution, namely the condition of the Organizing institution.

\subsection{Discussion}

In this discussion about the testing carried out based on questionnaire data that has been filled and processed.

\section{- Test Reliability and Validity}

In table 3 and table 4 explain the results of reliability and valid testing of processed data using SPSS version 24 (Statistical Package for the Social Sciences). 
Table 3. Reliability Statistic

\begin{tabular}{rrrr}
\hline \multicolumn{4}{c}{ Reliability Statistics } \\
\hline Cronbach's Alpha & Cronbach's Alpha Based on Standardized Items & N of Items \\
, 984 & & 985 & 81 \\
\hline
\end{tabular}

In table 3 shows based on testing data from variable $\mathrm{Y}$ to X85, the value of Cronbach's Alpha $0.984>0.1654$ means that the data tested is reliability.

Table 4. Item-Total Statistic

\begin{tabular}{|c|c|c|c|c|c|}
\hline \multicolumn{6}{|c|}{ Item-Total Statistics } \\
\hline Responden & $\begin{array}{l}\text { Scale Mean if } \\
\text { Item Deleted }\end{array}$ & $\begin{array}{l}\text { Scale Variance if } \\
\text { Item Deleted }\end{array}$ & $\begin{array}{l}\text { Corrected Item- } \\
\text { Total Correlation }\end{array}$ & Remark & $\begin{array}{c}\text { Cronbach's } \\
\text { Alpha if Item } \\
\text { Deleted }\end{array}$ \\
\hline Y1 & 257,8900 & 1025,493 & 0,615 & Valid & 0,984 \\
\hline Y2 & 258,0300 & 1021,221 & 0,666 & Valid & 0,984 \\
\hline Y3 & 258,0800 & 1021,872 & 0,689 & Valid & 0,984 \\
\hline Y4 & 258,0700 & 1026,490 & 0,514 & Valid & 0,984 \\
\hline Y5 & 258,5100 & 1020,757 & 0,582 & Valid & 0,984 \\
\hline $\mathrm{X} 11$ & 258,0300 & 1028,494 & 0,508 & Valid & 0,984 \\
\hline $\mathrm{X} 12$ & 258,0200 & 1024,686 & 0,627 & Valid & 0,984 \\
\hline X13 & 258,0600 & 1023,754 & 0,629 & Valid & 0,984 \\
\hline X14 & 258,2800 & 1018,264 & 0,685 & Valid & 0,984 \\
\hline X15 & 258,1800 & 1021,644 & 0,716 & Valid & 0,984 \\
\hline X16 & 258,1200 & 1020,349 & 0,639 & Valid & 0,984 \\
\hline X17 & 258,2100 & 1017,279 & 0,652 & Valid & 0,984 \\
\hline X18 & 258,1600 & 1021,004 & 0,677 & Valid & 0,984 \\
\hline X19 & 258,2100 & 1025,986 & 0,692 & Valid & 0,984 \\
\hline X110 & 258,1300 & 1018,538 & 0,671 & Valid & 0,984 \\
\hline $\mathrm{X} 111$ & 258,1800 & 1020,856 & 0,738 & Valid & 0,984 \\
\hline $\mathrm{X} 112$ & 258,0100 & 1023,162 & 0,666 & Valid & 0,984 \\
\hline X113 & 258,1200 & 1024,531 & 0,660 & Valid & 0,984 \\
\hline X114 & 258,1900 & 1017,549 & 0,710 & Valid & 0,984 \\
\hline $\mathrm{X} 115$ & 257,9600 & 1027,615 & 0,514 & Valid & 0,984 \\
\hline X116 & 258,0700 & 1027,237 & 0,509 & Valid & 0,984 \\
\hline X117 & 258,0000 & 1026,808 & 0,562 & Valid & 0,984 \\
\hline $\mathrm{X} 118$ & 258,2100 & 1020,531 & 0,634 & Valid & 0,984 \\
\hline X119 & 258,1000 & 1024,798 & 0,688 & Valid & 0,984 \\
\hline $\mathrm{X} 120$ & 258,1300 & 1023,852 & 0,642 & Valid & 0,984 \\
\hline $\mathrm{X} 121$ & 258,0900 & 1023,032 & 0,643 & Valid & 0,984 \\
\hline $\mathrm{X} 122$ & 258,0300 & 1025,201 & 0,597 & Valid & 0,984 \\
\hline $\mathrm{X} 123$ & 258,2500 & 1022,068 & 0,531 & Valid & 0,984 \\
\hline $\mathrm{X} 124$ & 258,1500 & 1020,048 & 0,616 & Valid & 0,984 \\
\hline $\mathrm{X} 125$ & 258,0800 & 1021,751 & 0,653 & Valid & 0,984 \\
\hline $\mathrm{X} 126$ & 258,1400 & 1023,697 & 0,632 & Valid & 0,984 \\
\hline X127 & 258,1300 & 1020,801 & 0,750 & Valid & 0,984 \\
\hline X128 & 258,0700 & 1023,904 & 0,723 & Valid & 0,984 \\
\hline X129 & 258,1800 & 1024,513 & 0,635 & Valid & 0,984 \\
\hline $\mathrm{X} 130$ & 258,2000 & 1027,192 & 0,555 & Valid & 0,984 \\
\hline $\mathrm{X} 21$ & 258,0300 & 1025,928 & 0,560 & Valid & 0,984 \\
\hline X22 & 258,0400 & 1019,918 & 0,703 & Valid & 0,984 \\
\hline
\end{tabular}




\begin{tabular}{|c|c|c|c|c|c|}
\hline \multicolumn{6}{|c|}{ Item-Total Statistics } \\
\hline Responden & $\begin{array}{l}\text { Scale Mean if } \\
\text { Item Deleted }\end{array}$ & $\begin{array}{l}\text { Scale Variance if } \\
\text { Item Deleted }\end{array}$ & $\begin{array}{l}\text { Corrected Item- } \\
\text { Total Correlation }\end{array}$ & Remark & $\begin{array}{c}\text { Cronbach's } \\
\text { Alpha if Item } \\
\text { Deleted }\end{array}$ \\
\hline $\mathrm{X} 23$ & 258,0600 & 1020,340 & 0,700 & Valid & 0,984 \\
\hline X24 & 257,9900 & 1022,454 & 0,622 & Valid & 0,984 \\
\hline $\mathrm{X} 25$ & 257,9900 & 1020,535 & 0,709 & Valid & 0,984 \\
\hline X31 & 258,1500 & 1023,684 & 0,681 & Valid & 0,984 \\
\hline X32 & 258,2200 & 1018,598 & 0,722 & Valid & 0,984 \\
\hline X33 & 258,1600 & 1016,156 & 0,762 & Valid & 0,984 \\
\hline X34 & 258,0600 & 1021,835 & 0,751 & Valid & 0,984 \\
\hline X35 & 258,0500 & 1019,018 & 0,775 & Valid & 0,984 \\
\hline X36 & 258,1700 & 1023,112 & 0,553 & Valid & 0,984 \\
\hline X37 & 258,1600 & 1022,378 & 0,641 & Valid & 0,984 \\
\hline X38 & 258,1000 & 1019,606 & 0,788 & Valid & 0,984 \\
\hline X41 & 258,3300 & 1012,062 & 0,659 & Valid & 0,984 \\
\hline X42 & 258,3000 & 1015,909 & 0,630 & Valid & 0,984 \\
\hline X43 & 258,2200 & 1020,880 & 0,682 & Valid & 0,984 \\
\hline X44 & 258,1800 & 1023,402 & 0,645 & Valid & 0,984 \\
\hline $\mathrm{X} 45$ & 258,1500 & 1023,503 & 0,687 & Valid & 0,984 \\
\hline X51 & 258,0600 & 1023,350 & 0,682 & Valid & 0,984 \\
\hline X52 & 258,0900 & 1025,901 & 0,603 & Valid & 0,984 \\
\hline $\mathrm{X} 53$ & 258,1700 & 1022,971 & 0,746 & Valid & 0,984 \\
\hline X54 & 258,1500 & 1020,351 & 0,670 & Valid & 0,984 \\
\hline $\mathrm{X} 55$ & 258,0700 & 1020,167 & 0,655 & Valid & 0,984 \\
\hline X56 & 258,2600 & 1023,386 & 0,552 & Valid & 0,984 \\
\hline X61 & 258,1000 & 1027,303 & 0,589 & Valid & 0,984 \\
\hline X62 & 258,2000 & 1022,040 & 0,676 & Valid & 0,984 \\
\hline X63 & 258,0400 & 1023,554 & 0,744 & Valid & 0,984 \\
\hline X64 & 258,2100 & 1020,491 & 0,750 & Valid & 0,984 \\
\hline X65 & 258,1500 & 1024,290 & 0,642 & Valid & 0,984 \\
\hline X66 & 258,1400 & 1023,718 & 0,673 & Valid & 0,984 \\
\hline X67 & 258,1200 & 1019,238 & 0,650 & Valid & 0,984 \\
\hline X68 & 258,1200 & 1019,844 & 0,685 & Valid & 0,984 \\
\hline X69 & 257,9200 & 1026,721 & 0,628 & Valid & 0,984 \\
\hline X71 & 258,0600 & 1020,279 & 0,723 & Valid & 0,984 \\
\hline $\mathrm{X} 72$ & 258,0000 & 1025,111 & 0,651 & Valid & 0,984 \\
\hline X73 & 258,0900 & 1020,689 & 0,727 & Valid & 0,984 \\
\hline X74 & 258,0700 & 1026,369 & 0,531 & Valid & 0,984 \\
\hline X75 & 258,0900 & 1021,436 & 0,707 & Valid & 0,984 \\
\hline X76 & 258,1900 & 1022,802 & 0,715 & Valid & 0,984 \\
\hline X77 & 258,0400 & 1024,059 & 0,700 & Valid & 0,984 \\
\hline X78 & 258,0600 & 1022,158 & 0,716 & Valid & 0,984 \\
\hline X81 & 257,9600 & 1021,817 & 0,667 & Valid & 0,984 \\
\hline X82 & 257,9500 & 1019,866 & 0,716 & Valid & 0,984 \\
\hline X83 & 258,1100 & 1017,392 & 0,741 & Valid & 0,984 \\
\hline X84 & 258,1000 & 1019,808 & 0,734 & Valid & 0,984 \\
\hline X85 & 258,0500 & 1021,523 & 0,631 & Valid & 0,984 \\
\hline
\end{tabular}

In Table 5 show on that the data variables $\mathrm{Y}$ to $\mathrm{X} 85$ are valid. 


\section{- Normality test}

Table 6. Normality test

\begin{tabular}{ccll}
\hline No & Variable & \multicolumn{1}{c}{ Variable Name } & Result \\
\hline 1. & $\mathrm{Y}$ & E-Learning & Normal \\
2. & $\mathrm{X} 1$ & System Performance & Normal \\
3. & $\mathrm{X} 2$ & System Security & Normal \\
4. & $\mathrm{X} 3$ & E-Readiness & Normal \\
5. & $\mathrm{X} 4$ & Behavior & Normal \\
6. & $\mathrm{X} 5$ & Management & Normal \\
7. & $\mathrm{X} 6$ & Effective & Normal \\
8. & $\mathrm{X} 7$ & Efficient & Normal \\
9. & $\mathrm{X} 8$ & Organizing Institution & Normal \\
\hline
\end{tabular}

Hypothesis:

H0: Data Distributed Normal

H1: Data is not Normal Distribution

\section{- Correlation and Determination}

Table 7. Model Summary

Model Summaryb

\begin{tabular}{cccccc}
\hline Model & $\mathrm{R}$ & R Square & Adjusted R Square & $\begin{array}{c}\text { Std. Error of the } \\
\text { Estimate }\end{array}$ & Durbin-Watson \\
\hline 1 &, $787^{\mathrm{a}}$ &, 619 &, 585 & 1,532 & 1,790 \\
\hline
\end{tabular}

a. Predictors: (Constant), X8, X4, X1, X2, X5, X7, X3, X6

b. Dependent Variable: Y

\section{- $\quad \mathbf{R}$ (Correlation Coefficient)}

The amount of $\mathrm{R}=0.787$ shows the correlation between e-Learning variables (Y) with System Performance (X1), System Security (X2), e-Readiness (X3), Behavior (X4), Management (X5), Effective (X6), Efficient (X7), Organizing Institution (X8) of 0.787 $(78.7 \%)$

So the level of relationship between e-Learning variables (Y) as the dependent variable with independent variables consists of System Performance (X1), System Security (X2), e-Readiness (X3), Behavior (X4), Management (X5), Effective (X6), Efficient (X7), Organizing Institution (X8) of 0.787 (78.7\%).

- $\quad$ Adjusted R Square (R2 or coefficient of determination)

Adjusted R Square size $=0.585$ shows $58.5 \%$ variation of e-Learning variable $(\mathrm{Y})$ with System Performance (X1), System Security (X2), e-Readiness (X3), Behavior (X4), Management (X5), Effective (X6), Efficient (X7), Organizing Institution (X8) while $41.5 \%$ due to other variations.

\section{- Standard Error}


Large Std Error of the Estimate $=1.532$ shows a variation of 1.532 around the regression line. The smaller the value of Std. Error of the Estimate will make the regression model more precise in predicting the dependent variable.

\section{- Simultaneous Significance Test}

Table 8. Anova

\begin{tabular}{clccccc}
\multicolumn{8}{c}{ ANOVA $^{\text {a }}$} \\
\hline Model & & Sum of Squares & df & Mean Square & F & Sig. \\
\hline \multirow{2}{*}{1} & Regression & 346,954 & 8 & 43,369 & 18,476 &, $000^{\mathrm{b}}$ \\
& Residual & 213,606 & 91 & 2,347 & & \\
& Total & 560,560 & 99 & & & \\
\hline
\end{tabular}

a. Dependent Variable: Y

b. Predictors: (Constant), X8, X4, X1, X2, X5, X7, X3, X6

\section{Hypothesis:}

Ho: There is no relationship between E-Learning variables (Y) with System Performance (X1), System Security (X2), E-Readiness (X3), Behavior (X4), Management (X5) Effective (X6), Efficient (X7), Organizing Institution (X8).

H1: There is a relationship between E-Learning variables (Y) with System Performance (X1), System Security (X2), E-Readiness (X3), Behavior (X4), Management (X5), Effective (X6), Efficient ( X7), Organizing Institution (X8).

\section{The test uses the $\mathrm{F}$ test}

Fcount $=18,476$ with comparison Ftable $=\mathrm{F}[0.05(8.91)]=2.31$

\section{Test result :}

Because $\mathrm{F}$ count $>$ Ftable then Ho is rejected

\section{Conclusion:}

There is a relationship between E-Learning variables (Y) with System Performance (X1), System Security (X2), E-Readiness (X3), Behavior (X4), Management (X5), Effective (X6), Efficient (X7), Organizing Institution (X8).

\section{Testing using Sig}

Sig $=0,000$ with comparison $\alpha=0.05$

\section{Test result :}

Because Sig $<\alpha$ Ho is rejected

\section{Conclusion:}

There is a relationship between E-Learning variables (Y) with System Performance (X1), System Security (X2), E-Readiness (X3), Behavior (X4), Management (X5), Effective (X6), Efficient (X7), Organizing Institution (X8) 
Table 9. Coefficients

\begin{tabular}{|c|c|c|c|c|c|c|c|c|}
\hline \multicolumn{9}{|c|}{ Coefficients $^{\mathrm{a}}$} \\
\hline & \multirow[t]{2}{*}{ Model } & \multicolumn{2}{|c|}{$\begin{array}{c}\text { Unstandardized } \\
\text { Coefficients }\end{array}$} & \multirow{2}{*}{$\begin{array}{c}\text { Standardized } \\
\text { Coefficients } \\
\text { Beta } \\
\end{array}$} & \multirow[t]{2}{*}{$\mathrm{t}$} & \multirow[t]{2}{*}{ Sig. } & \multicolumn{2}{|c|}{$\begin{array}{c}\text { Collinearity } \\
\text { Statistics }\end{array}$} \\
\hline & & $\mathrm{B}$ & Std. Error & & & & Tolerance & VIF \\
\hline \multirow[t]{9}{*}{1} & (Constant) & 2,200 & 1,265 & & 1,739 &, 085 & & \\
\hline & $\mathrm{X} 1$ & ,027 & 103 & ,027 & 265 & ,792 & ,407 & 2,459 \\
\hline & $\mathrm{X} 2$ & ,154 & , 102 & 163 & 1,508 & ,135 & ,359 & 2,789 \\
\hline & $\mathrm{X} 3$ & ,313 & ,124 & ,324 & 2,515 & ,014 & ,252 & 3,970 \\
\hline & $\mathrm{X} 4$ & ,130 & ,089 & , 152 & 1,467 & , 146 & ,390 & 2,566 \\
\hline & $\mathrm{X} 5$ & ,051 & ,133 &, 051 & ,382 & ,704 & ,231 & 4,334 \\
\hline & X6 &,- 023 & ,151 &,- 022 &,- 154 &, 878 & ,210 & 4,756 \\
\hline & X7 & ,142 & ,126 & ,138 & 1,124 & ,264 & ,280 & 3,575 \\
\hline & $\mathrm{X} 8$ &, 067 & 103 &, 075 & ,646 &, 520 &, 312 & 3,203 \\
\hline
\end{tabular}

a. Dependent Variable: Y

\section{Regression Statement:}

$\mathrm{Y}=2,200+0,027 \mathrm{X} 1+0,154 \mathrm{X} 2+0,313 \mathrm{X} 3+0,130 \mathrm{X} 4+0,051 \mathrm{X} 5-0,023 \mathrm{X} 6+0,142 \mathrm{X} 7$ $+0,067 \mathrm{X} 8$.

Or

e-Learning $=2,200+0,027$ System Performance $+0,154$ System Security $+0,313$ eReadiness + 0,130 Behavior + 0, 051 Management - 0,023 Effective + 0,142 Efficient + 0,067 Organizing Institution.

Of the seven independent variables included in the e-Learning variable regression model is not significant because the Sig $>0.05$ value is only the e-Readiness variable is significant because Sig $<0.05$.

So it can be concluded that e-Learning variables are influenced by e-Readiness. Associated with respondents from several universities. Relationship ( $\mathrm{Y}=0.313 \mathrm{X} 3$ or e-Learning $=0.313$ e-Readiness).

\section{- Multikolonieritas Test}

Table 10. Multikolonieritas Test

Coefficientsa

\begin{tabular}{|c|c|c|c|}
\hline & \multirow{2}{*}{ Model } & \multicolumn{2}{|c|}{ Collinearity Statistics } \\
\hline & & Tolerance & VIF \\
\hline \multicolumn{4}{|c|}{ (Constant) } \\
\hline \multirow{8}{*}{1} & $\mathrm{X} 1$ & ,407 & 2,459 \\
\hline & $\mathrm{X} 2$ & 359 & 2,789 \\
\hline & $\mathrm{X} 3$ &, 252 & 3,970 \\
\hline & $\mathrm{X} 4$ & ,390 & 2,566 \\
\hline & X5 &, 231 & 4,334 \\
\hline & X6 & 210 & 4,756 \\
\hline & $\mathrm{X} 7$ & 280 & 3,575 \\
\hline & $\mathrm{X} 8$ & ,312 & 3,203 \\
\hline
\end{tabular}

a. Dependent Variable: Y 
Table 10 explains that of the eight independent variables in the e-Learning variable regression model (Y) with System Performance (X1), System Security (X2), e-Readiness (X3), Behavior (X4), Management (X5). ), Effective (X6), Efficient (X7), Organizing Institution (X8) VIF value $<10$ means there is no multicollinearity.

\section{Conclusion:}

So the independent variable consists of E-Learning variables (Y) with System Performance (X1), System Security (X2), E-Readiness (X3), Behavior (X4), Management (X5), Effective (X6), Efficient (X7), the Organizing Institution (X8) does not indicate the existence of multicolonity.

\section{- Autocorrelation Test}

Table 11. Model Summary

\begin{tabular}{cccccc}
\multicolumn{7}{c}{ Model Summary $^{\mathbf{b}}$} \\
\hline Model & $\mathrm{R}$ & R Square & Adjusted R Square & $\begin{array}{c}\text { Std. Error of the } \\
\text { Estimate }\end{array}$ & Durbin-Watson \\
\hline 1 &, $787^{\mathrm{a}}$ &, 619 &, 585 & 1,532 & 1,790 \\
\hline
\end{tabular}

a. Predictors: (Constant), X8, X4, X1, X2, X5, X7, X3, X6

b. Dependent Variable: Y

The Durbin-Watson $(\mathrm{DW})$ value $=1.790$ compared to the table value with $\alpha=5 \%$, the number of independent variables $\mathrm{k}=8$ and the number of samples $\mathrm{n}=100$, then obtained DW tables: $\mathrm{dl}=1,5060$ and $\mathrm{du}=1,8498$ with Boundaries bottom: $4-\mathrm{du}=4-1,8498=2,1502$ and upper limit: $4-\mathrm{dl}=4-1,5060=2,494$.

It means there is no clarity of autocorrelation (without decision) because if $\mathrm{dL}<\mathrm{DW}<\mathrm{dU}$ or ( 4 - dU) $<$ DW $<(4-d L)$ (result of calculation: Dl $(1,5060)<1,790<1,8498)$.

\section{- Uji T}

In this $\mathrm{T}$ test there are two courses which are tested based on data before and after the implementation of e-Learning, namely Information System Audit Courses and Knowledge Management Courses.

Table 12. Pair Samples Statistics Before and After the Application of e-Learning for Information System Audit Courses

Paired Samples Statistics

\begin{tabular}{lccccc}
\hline & & Mean & N & Std. Deviation & Std. Error Mean \\
\hline Pair & Before & 67.83 & 12 & 18.925 & 5.463 \\
1 & After & 80.50 & 12 & 4.442 & 1.282 \\
\hline
\end{tabular}

Table 12 explains the application of e-Learning for Information System Audit Courses experiencing an increase in the average value of 12.67 results from 67.83 to 80.50 . 
Table 13. Level of Relationship between Average values for Information System Audit Courses

Paired Samples Correlations

\begin{tabular}{lllcl}
\hline & & $\mathrm{N}$ & Correlation & Sig. \\
\hline Pair 1 & Before After & 12 & .793 & .002 \\
\hline
\end{tabular}

In table 13 describes the level of relationship value The average value of the System Audit Course Information before and after applied e-learning is 0.793 or $79.3 \%$.

Table 14. Pair Samples Test for Information System Audit Courses

Paired Samples Test

\begin{tabular}{|c|c|c|c|c|c|c|c|c|c|}
\hline \multicolumn{10}{|c|}{ Paired Samples Test } \\
\hline & & \multirow{3}{*}{ Mean } & \multirow{3}{*}{$\begin{array}{c}\text { Std. } \\
\text { Deviation }\end{array}$} & \multicolumn{3}{|c|}{ Paired Differences } & \multirow{3}{*}{$\mathrm{t}$} & \multirow{3}{*}{ df } & \multirow{3}{*}{$\begin{array}{c}\text { Sig. } \\
\text { (2-tailed) }\end{array}$} \\
\hline & & & & \multirow{2}{*}{$\begin{array}{l}\text { Std. Error } \\
\text { Mean }\end{array}$} & \multicolumn{2}{|c|}{$\begin{array}{l}95 \% \text { Confidence Interval } \\
\text { of the Difference }\end{array}$} & & & \\
\hline & & & & & Lower & Upper & & & \\
\hline $\begin{array}{l}\text { Pair } \\
1\end{array}$ & $\begin{array}{l}\text { Before } \\
\text { After }\end{array}$ & -12.667 & 15.640 & 4.515 & -22.604 & -2.730 & -2.806 & 11 & .017 \\
\hline
\end{tabular}

\section{Hypothesis :}

H0 : There is no difference in the average value of the Information System Audit course before and after e-Learning is applied

H1 : There are differences in the average value of Information System Audit courses before and after e-Learning is applied

\section{Data Testing:}

Using Sig

Sig. $(2$-tailed $)=0.017$, then $\operatorname{Sig}=0.0085$ with alpha comparison $=0.05=5 \%$

\section{Test result}

Because Sig < alpha, then H0 is rejected

\section{The conclusion:}

There is a difference in the average value of Information System Audit courses before and after e-Learning is applied.

\section{Conclusion}

From research on the role of e-Learning, conclusions can be drawn based on the formulation of the problem of (1) measuring effective and efficient learning using e-Learning, namely there is a relationship between $80 \%$ e-Learning and $97 \%$ efficient e-Learning, (2) ELearning is active has an overall impact based on Behavior (79\%), includes honesty (60\%), Trust (84\%), Messanger (84\%) and Intelligence (84\%). 


\section{References}

[1] U. D. Negara et al., "No Title," vol. 4, no. 1, pp. 1-12, 1945.

[2] "https_economictimes_indiatimes_com_definition_e_learning.pdf.".

[3] J. L. Torrecilla and J. Romo, "Data learning from big data," Stat. Probab. Lett., vol. 5, no. xxxx, pp. $1-5,2018$.

[4] W. Zhang and J. M. Rieckmann, "E-Learning Pedagogical Strategy : Present and Trends in Scientific Research," 2018 9th Int. Conf. Inf. Technol. Med. Educ., pp. 480-483, 2018.

[5] "2015_Expert Search Engine and Content Generation in E.".

[6] B. Klimova and P. Maresova, "Cloud Computing and E-Learning and Their Benefits for the Institutions of Higher Learning," pp. 75-78, 2016.

[7] S. Ahmed, "The Role of e-Learning to Face the Challenges of the Century في مواجهة تحديات القرن

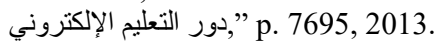

[8] D. Eg and O. Hvkpdw, “( IILFLHQW 0HWKRG IRU ) DFH 5HFRJQLWLRQ DQG, WV 5ROH LQ 6XSSRUWLQJ ( OHDUQLQJ 6 \VWHPV,” pp. 5-8, 2015.

[9] "S. Arora, J. Maini, P. Mallick, P. Goel and R. Rastogi, 'Efficient E-learning management system through web socket,' 2016 3rd International Conference on Computing for Sustainable Global Development (INDIACom) , New Delhi, 2016, pp. 509-512.," p. 7724316, 2016.

[10] M. B. Yel, "E-Learning Model for Equivalency Education Program in Indonesia," no. September, pp. 19-21, 2017.

[11] H. Jusuf and A. Azimah, "E-learning for facilitating learning," no. Icic, pp. 1-4, 2016.

[12] A. Kanimozhi, "An Adaptive E-Learning Environment Centred On Learner's Emotional Behaviour."

[13] C. P. Herath, "Stakeholders ' Psychological Factors Affecting E- Learning Readiness in Higher Education Community in Sri Lanka," pp. 168-173, 2015.

[14] A. Nortvig, A. K. Petersen, and S. H. Balle, "A Literature Review of the Factors Influencing E-Learning and Blended Learning in Relation to Learning Outcome , Student Satisfaction and Engagement," vol. 16, no. 1, pp. 46-55, 2018.

[15] S. Liaw and G. Chen, "Surveying instructor and learner attitudes toward e-learning," vol. 49, pp. 1066-1080, 2007.

[16] C. R. Bomhold, "Educational use of smart phone technology undergraduate university students," 2005. 